\title{
Derleme
}

Mersin Üniv Saglık Bilim Derg 2020;13(3):457-464

doi:10.26559/mersinsbd.763836

\section{Yeni koronavirüs hastalığı (covıd-19) ile ilgili yanlış bilgilerle mücadele yöntemleri}

\author{
Gözde Alpyıldız¹, (Dilek Aslan² \\ ${ }^{1}$ Hacettepe Üniversitesi Sağlık Bilimleri Enstitüsü Halk Sağlığı AD Yüksek Lisans Prg. \\ ${ }^{2}$ Hacettepe Üniversitesi Tıp Fakültesi Halk Sağlı̆̆ı AD
}

\section{Öz}

Yeni Koronavirüs Hastalığı (COVID-19) ile ilgili toplumda zihinlerde karışıklığa neden olan ve sağlık davranışlarını olumsuz yönde etkileyen bazı yanlış bilgiler mevcuttur. Bu yazı kapsamında COVID-19 ile ilgili toplumda var olan yanlış bilgilerin yayılmasının önlenmesi için önerilerin sunulması amaçlanmıştır. Çalışma sürecinde COVID-19 ile ilgili yazılı ve görsel medya, gündem izlenmiştir. Yanlış bilginin yayılmasında sağlığın belirleyicileri de dâhil olmak üzere birden çok faktör bulunmaktadır. Yanlış bilgi, bireylerde yanlış davranışın oluşmasına neden olmaktadır. Dolayısıyla, sistematik bir şekilde önleme yaklaşımları gerekmektedir.

Anahtar kelimeler: Halk sağlığı, önleme, pandemi, yanlış bilgi, Yeni Koronavirüs Hastalığı

\section{Strugglemethods on misinformationaboutNovelCoronavirusDisease (COVID-19)}

\begin{abstract}
There is misinformation about the Novel Coronavirus Disease (COVID-19) which causes confusion in mind and influence health behaviors negatively in the community. Within the scope of this article, it is aimed to present recommendations to prevent the spread of misinformation about COVID-19 in the society. During the study, the written and visual media and the agenda regarding COVID-19 were followed. There are multiple factors, including the determinants of health, in the spread of misinformation. "Wrong" information ends with "wrong" health behaviors of the individuals. In this regard, systematic prevention approaches are needed.
\end{abstract}

Keywords: Public health, prevention, pandemic, misinformation, Novel Coronavirus Disease

Yazının geliş tarihi: 03.07.2020 Yazının kabul tarihi:25.09.2020

Sorumlu yazar: Gözde Alpyıldız, Hacettepe Üniversitesi Sağlık Bilimleri Enstitüsü, Ankara, Tel: 0537 0478078, E-posta: gozdealpyildiz@hotmail.com 


\section{Giriş}

"Yeni Koronavirüs Hastalığı (COVID19)", SARS-CoV-2 virüsünün neden olduğu bir infeksiyon hastalığıdır. Hastalık ilk olarak Çin'in Vuhan şehrinde 2019 yılı Aralık ayı sonlarında ateş, öksürük, nefes darlığı şeklinde solunum yolu belirtileri gelişen bir grup hastada tanımlanmıştır." ${ }^{1}$ Hastalık, tanımlanmasının ardından, dünyada yayılımını sürdürmüştür. Hastalığın kıtalar arasında yayılması ve pek çok ülkede ciddi boyutlara ulaşması nedeniyle Dünya Sağlık Örgütü (DSÖ) tarafından salgın "dünyada birden fazla kıtada ve çok sayıda ülkede etkisini gösteren salgın hastalıklar için kullanılan" "pandemi" olarak ilan edilmiştir. Pandemide, hastalıkla ilgili bir yandan mevcut hastaların tedavisi ve virüsün yayılımının önüne geçilmesi için çabalar sürerken bir yandan da yeni bilgiler edinilmekte, bilimsel çalışmalar yapılmakta, yaklaşımlar sıklıkla güncellenmektedir.,2,3 Hastalıkla ilgili doğru zamanda doğru davranışların eksiksiz uygulanabilmesi için bilgi kaynaklarının eksiksiz, güncel ve kanıta dayalı olması gerekmektedir. ${ }^{3} \mathrm{Bu}$ konuda başlangıçtan bu yana toplumda farklı kanallardan bilgilendirmeler yapilmaktadır. Kamusal ve diğer bilgi kaynakları toplum ve sağlık çalışanları tarafından yakından takip edilmektedir. ${ }^{4}$ Bununla birlikte, COVID-19 sürecinde toplumun yanlış yönlenmesine neden olan gerçek dışı bilgiler olduğuna dair veriler de yer almaktadır. ${ }^{5}$

$\mathrm{Bu}$ yazı kapsamında COVID-19 ile ilgili toplumda var olan yanlış bilgilerin yayılmasının önlenmesi için önerilerin sunulması amaçlanmıştır. İçerikte; yanlış bilgi ile ilgili güncel kavramlara, COVID-19 sürecinde yanlış bilgi örneklerine, durumu yaratan olası nedenlere ve çözümlere ilişkin önerilere yer verilmiştir.

\section{COVID-19 sürecinde yanlıs bilgi ve örnekleri}

Yeni Koronavirüs Hastalığı ile ilgili toplumda zihinlerde karışıklığa neden olan ve sağlık davranışlarını etkileyen birtakım yanlış bilgiler mevcuttur. Yanlış bilgi "bilimsel delil yetersizliğinden dolayı şu anda yanlış olan bir iddia" olarak tanımlanmaktadır. Yanlış bilgiler kısıtlama olmaksızın yayılmakta, herhangi bir iyileștirme, hakemlik veya profesyonel doğrulama gerektirmemektedir. ${ }^{6}$

Toplumda yanlış bilgilerin yayılması ile ilgili son dönemlerde "infodemi" sözcüğü bilimsel literatürde sık kullanılmaktadır. İnfodemi, yanlış bilgi salgını olarak tanımlanmaktadır.7 "Dezenformasyon" sözcüğü de yanlış veya yanıltıcı bilgilere atıfta bulunmaktadır. Bu gibi yanlış bilgiler halk sağlığını tehdit etmektedir. ${ }^{8}$

\section{Yanlıs bilgi/infodemi örnekleri}

Dünya Sağlık Örgütü tarafından toplumda yaygın olarak bilinen "yanlış" bilgilerden bazıları arasında; "Yeni koronavirüs sicak ve nemli bölgelerde bulaşmaz", "Soğuk havalarda koronavirüs ölür", "Çok sicak suyla duş almak hastalığa yakalanmayı önler", "Ağzı ve burnu düzenli olarak tuzlu su ile çalkalamak yeni koronavirüs hastalı̆̆ını önler", "Sarımsak koronavirüsten korur", "Evcil hayvanlar yeni koronavirüsle enfekte olup hastalığı bulaştırabilir", "Antibiyotikler koronavirüse fayda edebilir", "Yeni Koronavirüs hastalığından sadece yaşlı ve kronik hastalığı olanlar etkilenir"9 gibi söylemler bulunmaktadır. Bu söylemler DSÖ tarafından güncel olarak yalanlanmakta ve doğruları toplum ile paylaşılmaktadır. ${ }^{7}$

COVID-19 ile ilgili yanlış bilgi ve söylentiler, sağlıklı davranışlarını (el yıkama, sosyal mesafe vb.) maskelemiştir. Virüsün yayılmasını artıran ve kötü sonuçlar doğuran hatalı uygulamaları beraberinde getirmiştir. Örneğin Hindistan'da, üç çocuk sahibi bir babanın COVID-19 teşhisini duyması üzerine intihar ettiği bildirilmiştir. Yine, Nijerya'da, infodemi nedeniyle sitma paraziti tedavisinde kullanılan ve COVID-19'da etkili olduğu düşünülen bir ilaç fazla dozda kullanılmıştır. ${ }^{10}$

Basının ve sosyal medyanın COVID19'a yönelik "veba" ve "klyamet" gibi kelimeleri kullanması halkta korku ve endişeyi arttırmıştır. Bir sosyal medya platformunu analiz eden Pulido ve 
arkadaşları, yanlış bilginin bilime dayalı kanıtlardan daha fazla paylaşıldığını bulmuştur. ${ }^{11,12}$

Aldatma niyetiyle formüle edilmiş sahte haberler damgalamaya yol açmıştır. Yanlış bilgiler, saldırı olarak algılanmıştır. C vitamini, bal ve kolloidal gümüşün koronavirüsü tedavi edeceği iddiaları sosyal medyada yayılmıştır. ${ }^{13}$

Pandeminin başında virüsün grip benzeri olduğu, bağışıklığı güçlü tutmanın virüsle savaşmada yeterli olacağ $\breve{l}_{1}$ gibi iddialar Türkiye'de yayılmıştır. ${ }^{14}$ Salgın başladığında koronavirüsle ilgili komplo teorileri sosyal medyadan yayılmış ve bazıları Türkiye'de de karşılık bulmuştur. Kasım 2019'da Çin'de ortaya çıkan COVID19'un, 5G teknolojisinin hayata geçişi nedeniyle bağışıklığı düşürdüğü iddia edilmiștir. Hatta bu iddia Türkiye'de bazı köşe yazarları tarafından gündeme getirilmiștir. ${ }^{15,16}$

Bir üniversitenin ya da uluslararası saygın kuruluşların adları kullanılarak yapılan sahte haberler toplumu olumsuz etkilemiştir. ${ }^{17}$ Oxford Üniversitesi Reuters Enstitüsü'nün araştırma raporunda, COVID19'a ilişkin yanlış bilgilerin \%38'inin uydurma, \%59'unun bağlamından koparılmış olduğu açlklanmıştır. Araştırmanın sonucunda yanlış bilgilerin \%59'unun "yeniden şekillendirildiği" ortaya çlkmıştır. ${ }^{18}$ Bu çalışmada 7 Nisan 2020'de yayınlanan grafiklere göre Ocak ayının yarısından sonra paylaşılan bilgilerde artma görülmüştür. ${ }^{19}$ Sosyal medyadaki sahte haberler, ulusal sağlık hizmetleri tarafından desteklenen kanıta dayalı önlemlere olan ilgiyi azaltmıştır. ${ }^{20}$ İnternette "koronavirüsten korunma" başlıklı aramada ortaya çıkan bilgilerin değerlendirildiği bir çalışmada, bilgi kaynaklarının yarısından fazlasının maske kullanımı konusunda yanlış bilgi içerdiği bulunmuştur. ${ }^{21} 15$ Mart 2020 tarihinde sosyal medyada atılan bir içeriğe göre; COVID-19'un akciğere inmeden önce dört gün boğazda kaldığı, tuz, sıcak su ve sirkeyle gargara yapmayla virüse müdahale edilebildiği yanlış bilgisi yayılmıştır. Fakat koronavirüsün dört gün boğazda kaldığına ve COVID-19 ile mücadelede bu iddiaya ilişkin bilimsel çalışmanın olmadığı ortaya çıkmıștır.22 Bir diğer infodemi; COVID-19'un, bir içecek firmasıyla yayılmaya çalışıldığı iddiası olmuştur. ABD Hastalık Önleme ve Kontrol Merkezi (CDC) tarafindan, COVID19'un gıda yoluyla bulaştığına dair bilimsel kanıt olmadı̆̆ belirtilmiştir. ${ }^{22}$ SARS-CoV2'nin bulaştırıcılığının artması ve mutasyona uğraması hakkındaki asılsız spekülasyonlar da infodemi açısından örnekler arasında yerini almıştır. ${ }^{23}$

Toplumda bazı antiinflamatuar ilaçların koronavirüsle enfekte olma riskini arttırdığı yanlış bilgisi yayılmıştır. Dünya Sağlık Örgütü, infodemiyi önlemek için bir WhatsApp hizmeti sunmuştur ancak dezenformasyonun sosyal ağlarda hızla yayılmasına engel olamamıștır. ${ }^{20}$ İtalya'da, Whatsapp ile yayllan bir diğer infodemi örneği de Milanolu bir doktorun, yeni koronavirüsün asfaltta dokuz güne kadar yaşayabildiği ve dışarıda hep aynı ayakkabının kullanılması gerektiği yönünde olmuștur. ${ }^{22}$

\section{Infodeminin olası nedenleri}

İnfodeminin olası nedenleri arasında; sosyal medyadaki troller, komplo teorileri ve asılsız spekülasyonlar, tık odaklı habercilik tuzağı, medyanın ekonomik kaygısı, toplumun devletlere duyduğu güvensizlik, Neoliberalizmin etkisi, siyasi çıkar gütme, algı yönetimi ve manipülasyon, siberkondri ve anksiyete sağlık sorunlarının varlığı, bilişsel yükün artması, sosyal medya yorgunluğu, ön baskı makalelerde hata olması, yayınlanmıș makalelerde titiz hakem çalışmalarının olmaması, dergilerde yayınlanan kişisel yorumlar, halktaki panik, korku ve endişe durumu, verimsiz ve tutarsız hükümet mesajları, bilim topluluklarındaki tutarsız söylemler, pandemi sürecinin belirsizliği ve COVID-19'un henüz bilinen bir tedavisinin olmaması, post-truth dönem denilen gerçekleri uzaklaștırma arzusu, dijital medyanın koruma alt yapısının eksikliği, damgalanma, sosyal medyada sürekli ve yoğun olarak yanlış bilgiye maruz kalma sayılabilir.7,10,11,17,22,24-34

Sosyal medyada paniğe neden olan paylaşımlarla ilgili DSÖ Genel Direktörü bu paylaşımları, troller ve komplo teorileri olarak 
değerlendirmiș ve mücadele vurgusu yapmıştır. ${ }^{24}$

$\checkmark$ "Tık odaklı habercilik tuzăğı" diğer olası nedenlerden diye düşünülebilir. Ekonomik kaygılarla halkta merak uyandırarak yapılan dijital haberler, komplo teorileri, histeri, nefret ve yalan içermiştir. Bilimsel bilgi akışına engel olan yanlış bilgilendirme, kafa karıștırıcı veriler ve sahte haberler kamu sağlığı için tehlike oluşturmuştur. ${ }^{25}$

$\checkmark$ Toplumda duyulan güvensizlik diğer olası nedendir. Nitekim bu salgında sağlık çalışanları dâhil, toplumun büyük bir kısmı vakaların saklandığından kuşkulanmıștır. ${ }^{17} \mathrm{Bu}$ kapsamda yapılan bir araştırma sonuçlarına göre toplumun Mart ayında $\% 45$ 'i ve Mayıs ayında \%26'sı devletin yanlış bilgi verdiğine inanmıștır.26 Verimsiz hükümet mesajlarının olması ve bireysel düzeydeki yorumların infodemiye sebep olduğu gözlemlenmiştir. ${ }^{27} \mathrm{Bu}$ açıdan değerlendirildiğinde, devletin doğru ve güvenilir bilgi vermediği düşüncesi de olası nedenler arasında kabul edilebilir.

$\checkmark$ Salgın döneminde, sağlık politikaları ve sağlık harcamaları bütçeleri bütün dünyanın öncelikli konusu haline gelmiştir. ${ }^{28} \mathrm{Bu}$ süreçte diğer dünya ülkelerinin sağlık politikalarıyla kıyas yapılması, neoliberalizm akımı etkisiyle kamu sağlığının ekonomi içindeki ağırlığının azaltılmaya çalışılması ile panik artmış olabilir. COVID-19 tedavisi Amerika gibi neoliberal politika izleyen ülkelerde pahalıdır. ${ }^{29}$ COVID-19'a karșı tedavi hizmeti alamayacağını düşünen halk, sağlı hizmetinden yararlanamayacağı için panikle yanlış yöntemlere başvurmuş ve bu bilgileri yaymış olabilir.

$\checkmark$ Yeni Koronavirüs Hastalığı sürecinde dünyanın farklı yerlerinde insanlar gerçek bilgi ile hayal ürünü bilgiyi ayırt etmeye çabalamıştır. Doğru sağlık davranışları yerine bilimsel geçerliliği olmayan uygulamalar tercih edilebilmiștir. ${ }^{30} \mathrm{Bu}$ da bilimsel bilgiden uzaklaşılmasına neden olmuştur.

$\checkmark$ Manipülatörlerin pandemi ile ilgili verilen istatistikî bilgilerin doğru olmadığı ve asıl sayının verilmediğ $i$ söylemleriyle iletişim kaynaklarında algı yönetimi faaliyetleri diğer olası nedenler arasındadır. Bu kişiler, kurul üyelerinin isimlerini kullanarak sahte hesaplar açmış, halkı yanlış bilgilendirmiştir. $\mathrm{Bu}$ nedenle olası diğer neden; siyasi çlkar gütme durumudur. ${ }^{7}$

$\checkmark$ Dijital medyanın koruma alt yapısının eksikliği nedenler arasındadır. Bu koruma ve denetim eksikliği, kötü niyetli kişilerin yanlış bilgiyi paylaşmalarına rahat ortam yaratmaktadır. ${ }^{31}$

$\checkmark$ Siberkondri ve anksiyetesi olan kişilerin takıntıyla sağlık haberlerini araması ile aşırı bilgi yüklemesi durumu oluşmuştur. Sahte haberlerin çok olması bilişsel yükü artırmıștır.27,32 Artan bilişsel yük ile medya yorgunluğu oluşmuştur. Bu yanlış bilgilere maruz kalmak insanlarda paylaşma dürtüsünü artırmıştır. Bu durum, halkta kafa karışıklığına yol açmıştır.11

$\checkmark$ İnfodeminin bir kısmı bilimsel ortamlarda yeterince olgunlaşmayan, kanıt üretilemeyen verilerin topluma yansitılmasi nedeniyle meydana gelebilmektedir. Örneğin, SARS-CoV-2'nin viral özellikleri ile insan immün yetmezlik virüsü (HIV) arasında benzerliklerini anlatan bir ön baskı makalesi, biyomühendislik hakkında komplo teorilerini düşündürmüştür. Makale, ciddi eleștirilere maruz kalmış ve geri çekilmiştir. ${ }^{33}$

$\checkmark$ Gerçek ile gerçek olmayan arasındaki sınırların bulanıklaştığı, duyguların ve inançların gerçeklerden daha çok tercih edildiği dönem şeklinde tanımlanan "Post-truth" (hakikat ötesi) gibi kavramlar infodemi 
açısından hazırlayıcı bir zemin olabilir. ${ }^{22}$

$\checkmark$ Yeni Koronavirüs Hastalığı nedeniyle "damgalanan" bireylerin, hastalıkla ilgili kaygılarının artması nedeniyle infodemi öngörülmüștür. ${ }^{34}$

$\checkmark$ Sosyal medyada yoğun ve sürekli yanlış bilgiye maruz kalmak infodemiyi hızlandırarak halkın koruyucu sağlık davranışlarını gevşetmesine yol açmıştır. ${ }^{10}$

\section{Halk sağlığı bakış açısıyla nasıl önlemeli?}

Halk sağlığı bakış açısı; birincil, ikincil ve üçüncül korunma yaklaşımlarının kısa, orta ve uzun dönemde uygulanabilir şekilde sistematize edilmesine öncelik verir. Birincil korunma, durumun ortaya çıkmaması, ikincil korunma durum ortaya çıktığında yapılacaklar ve üçüncül korunma da durumun daha kötüye gitmemesi için alınacak önlemleri içermelidir.

Toplum sağlığı açısından önleyici yaklaşımlar daha etkili, daha kolay ve daha ucuz olduğundan birincil korunmaya ağırlık verilmelidir. İnfodeminin önüne geçmek için aşağıda bazı öneriler yer almaktadır:

\section{Birincil korunma yaklaşımıyla;}

$\checkmark$ Bireylerin yanlış bilgiye maruz kaldığ sosyal medya platformları belirlenmeli, bu ortamlara müdahaleler yapılmalıdır.

$\checkmark$ İnfodeminin kaynağı ve etkeni tespit edilmeli, bu çalışmalar rutin olarak tekrarlanmalıdır.

$\checkmark$ Yetkililer tarafından hızlı ve yerinde önlemler alınmalıdır.

$\checkmark$ Bireyler, yanlış bilgi paylaşımından kaçınmalı ve bilimsel kaynakları tercih etmelidir.

$\checkmark$ İnfodemiyi önlemeye yönelik kamu otoriteleri tarafından müdahale planları oluşturulmalı, bilginin paylaşılmasında sistemler geliştirilmelidir.

$\checkmark$ Bilginin sunulmasında uluslararası ortak dil kullanılmalı, bilgiye dijital ortamdan küresel erişim unutulmamalıdır. $\checkmark$ Pandemi, dünya üzerinde yaşayan herkesi ilgilendiren ortak (evrensel) bir sağlık sorunudur; dolayısıyla infodemiyi önlemede uluslararası iş birliği önem taşır. Doğru bilgiye erişebilmek için engellerin eşitlik ve hakkaniyet yaklaşımları ile kaldırılması uygun olur.

$\checkmark$ Olağanüstü durumlarda risk iletişimi sağlanmalıdır. Kuruluşlar arası bilgi alışverişi yapılmalıdır. İnfodemi riskini iyi yönetebilmek için risk iletişimi, uygun kanallar vasitasıyla açık, güvenilir, zamanında ve herkesi kapsayarak yapılmalıdır.

$\checkmark$ Dezenformasyonu önlemek amaciyla medyada da çeşitli önleyici uygulamalar yapılabilir. Zira yanlış bir bilgi almış olan insanların fikirlerini değiștirme yaklașımları kullanarak infodemiyle mücadelenin daha zor olduğu görülmüştür. ${ }^{13}$

$\checkmark$ Toplum, yetkin kişiler tarafından salgın konusunda bilinçlendirilmeli, COVID-19 koşullarına uygun eğitimler verilmelidir. Halkın, COVID-19 ile ilgili riski algılaması ve olumlu sağlık davranışı geliştirmesi sağlanmalıdır.

$\checkmark$ Doğru bilginin topluma ulaştırılması amacıyla farklı yöntemler kullanılabilir. Örneğin; COVID-19 sürecinde tele tıp kullanımı kamu alanında sağlık sistemine yardımcı olabilir ve destek sağlayabilir. ${ }^{36} \mathrm{Bu}$ uygulama ile birey, sağlık personelinden "aracısı" olarak doğru bilgiyi alabilir.

\section{İkincil korunma yaklaşımıyla;}

$\checkmark$ Verilerinin toplanması, analiz edilmesi ve geri bildirim verilmesi şeklindeki rutin sağlık bilgi sistemi olan sürveyans infodemiyle mücadele için de uygulanmalıdır.

$\checkmark$ Sağlık ve iletişim kuruluşları arasında bilgi alışverişi sağlanmalı ve infodeminin düzeltilmesi hususunda birlikte çalışmalıdır. COVID-19 ile ilgili bilinenler ve bilinmeyenlerin ayırt edilmesi konusunda sağlık çalışanları yardımcı olmalıdır. 
$\checkmark$ İnfodemiyle mücadele etmek için multidisipliner yaklaşım ile ekip çalışmaları yapılmalıdır.

$\checkmark$ Yanlış bilgiyi düzeltmek için medya kanallarına yetkin kişiler çıkarılmalıdır.

$\checkmark$ İnfodemi tespitine yönelik uluslararası veri toplama ve araştırma sistemleri geliştirilmelidir.

$\checkmark$ Damgalamanın önüne geçmek için ayrıștırıcı üslup kullanmaktan kaçınılmalıdır.

COVID-19

hastalığının herkes için olabileceği ve her kişiyi etkileyebileceği söylenmelidir.

$\checkmark$ Yerel topluluklar, gönüllü kişiler infodemiyle mücadelede şüpheli vakaları rapor etmelidir. Nitekim Çin Hükümeti ve halkı, infodemi üzerinde erken müdahale çalışmalarıyla başarı sağlamıştır. ${ }^{37}$

$\checkmark$ Bilimsel kaynaklardan yayılan infodemi ile mücadelede hakemler iyi değerlendirme yapmalıdır. Hatalı ön baskı makaleleri geri çekmek infodemiyi önlemede yetersiz kalabilir. Klinisyenlerin, akademisyenlerin ilk başvuru yerleri olan kanıt derecesi yüksek dergiler bu konuya dikkat etmelidir. Aynı zamanda kamu histerisi yaratan yanlış bilgiyle mücadele etmenin en iyi yolu, sağlık araştırmacıları tarafından üretilen güvenilir verilerdir. ${ }^{35}$ Dolayısıyla, pandeminin üstesinden gelmek için daha fazla araştırmaya ihtiyaç vardır.

\section{Üçüncül korunma yaklaşımıyla;}

$\checkmark$ İnfodemiyle mücadelede dünya ülkelerinin COVID-19'a yönelik bütünsel ve tutarlı hedefleri olmalıdır. Hükümetler, bilgilerin doğruluğu konusunda güvence vermelidir.

$\checkmark$ Komplo teorileri, nefret söylemleri, yalan haberler "saldırı" niteliğinde algılandığından toplumlarda barış, bilgi güvenliği sağlanmalıdır. Uluslararası ilişkiler kuvvetli tutulmalıdır. COVID-19'a yönelik

\author{
damgalama ve irkçılığın önüne \\ geçilmelidir. \\ $\checkmark$ Eğitim programlarına ağırlık \\ verilmelidir.
}

\section{Sonuç}

Ulusal ve uluslararası yardım gerektiren, toplumun sadece kendi olanaklarıyla baş edemeyeceği COVID-19 salgınında infodeminin olması halk sağlığını tehdit etmektedir. İnfodeminin önüne geçmek için önleme yaklaşımlarına ağırlık verilerek hazırlıklı olunmalıdır. Yanlış bilgiyle karşılaşıldığında durumu düzeltmek için hızlı ve sistematik bir şekilde geri dönüştürücü çalışmalar yapılmalı, güvenlik sorunları çözülmelidir. Önüne geçilemeyen durumlarda ise eğitim faaliyetlerine ağırlık verilmeli, ülkeler arası iş birliği yapılmalıdır. COVID-19 pandemisinde daha fazla kriz yaşanmadan ilgili her bileşen üzerine düşen sorumluluğu yapmalıdır.

Yazar katkısı: Yazarların tamamı çalışmanın planlanması, yürütülmesi, çalışma metninin yazılması aşamalarına aktif olarak katılmıştır.

Çıkar çatışması: Yazarların herhangi bir çıkar çakışması bulunmamaktadır.

Mali destek: Bu çalışma sırasında kamu, ticari veya kar amacı gütmeyen sektörlerdeki fon ajanslarından herhangi bir destek alınmamıştır.

\section{Kaynaklar}

1- Halka yönelik [İnternet]. 2020 [Erişim tarihi: 30 Mayıs 2020]. Erişim adresi: https://korona.hasuder.org.tr/siksorulan-sorular/

2- Til A. Yeni Koronavirüs Hastalığı (COVID-19) Hakkında Bilinmesi Gerekenler. Göller Bölgesi Aylık Ekonomi ve Kültür Dergisi. 2020; 8(85):53-57.

3- Alıcılar HE, Çöl M. Yeni Koronavirüs Salgını: Korunmada Etkili Yaklaşımlar. 2020; 1-8. 
4- Demirbilek Y, Pehlivantürk G, Özgüler Z, Alp Meşe E.COVID-19 outbreakcontrol, example of ministry of health of Turkey. Turk J MedSci. 2020; 50: 489-494.

5- LiHO-Y, BaileyA, Huynh D, ChanJ.YouTube as a source of information on COVID-19: a pandemic of misinformation?BMJ Global Health.2020;5:e002604.1-6.

6- Kouzy R, Jaoude J, Kraitem A, El Alam M, Karam B, Adib E ve ark. Coronavirus Goes Viral: Quantifying the COVID-19 Misinformation Epidemic on Twitter. Cureus. 2020; 12(3):1-9.

7- Kırık AM, Özkoçak V. Yeni dünya düzeni bağlamında sosyal medya ve yeni koronavirüs (COVID-19) pandemisi. Sobider. 2020;7(45):133154.

8- Liu P, Huang L. Digital Disinformation About COVID-19 and the Third-Person Effect: Examinig the Channel Differences and Negative Emotional Outcomes. Cyberpsychology, Behavior and Social Networking. 2020;1-5.

9- Coronavirus disease (COVID-19) advice for the public: Mythbusters [İnternet]. 2020[Erişim tarihi: 26 Mayıs 2020]. Erişim adresi: https://www.who.int/emergencies/ diseases/novel-coronavirus2019/advice-for-public/myth-busters

10- Tasnim S, Hossain Md, Mazumder H. Impact of rumorsormis information on Coronavirus disase (COVID-19) in socialmedia.

11- NG Hoong K, Kemp R. Understanding and reducing the fear of COVID-19. J Zhejiang Univ-Sci B.2020;1-3.

12- Pulido CM, Villarejo-Carballido B, Redondo-Sama G, et al.2020. COVID-19 infodemic: more retweets for science based information on coronavirus than for false information. Int Sociol, 35(4):377-392.

13- Vaidyanathan G. Finding a vaccine for misinformation. PNAS. 2020; 117(32):14.

Mersin Üniv Saglık Bilim Derg 2020;13(3)
14-Salgının en gözde yanlış bilgileri [İnternet]. 2020[Erişim tarihi: 17 Eylül 2020]. Erişim adresi: https://teyit.org/salginin-en-gozdeyanlis-bilgileri

15-Sosyal medyada koronavirüs paylaşımları: Doğru bilinen 10 yanlış [İnternet]. 2020[Erişim tarihi: 17 Eylül 2020]. Erişim adresi: https://tr.euronews.com/2020/04/03/ sosyal-medyada-koronaviruspaylasimlari-dogru-bilinen-10-yanliscorona-virus-covid-19

16- Başımıza kim sardı bu belayı: Komplo ve koronavirüs [İnternet]. 2020 [Erişim tarihi: 17 Eylül 2020].

Erişim adresi:https://www.birikimdergisi.com /dergiler/birikim/1/sayi-373-mayis2020-373/10040/basimiza-kim-sardibu-belayi-komplo-vekoronavirus/11774

17-Ergör G. Koronavirus pandemisinin düşündürdükleri. Turk J Public Health 2020; 18(1):99-102.

18-Rapor: Covid-19'a ilişkin yanlış bilgilerin yüzde 38'i uydurma, yüzde 59 'u bağlamından koparılmış [İnternet]. 2020 [Erişim tarihi: 10 Haziran 2020]. Erişim adresi: https://tr.euronews.com/2020/04/09/ rapor-covid-19-a-iliskin-bilgilerinyuzde-38-i-uydurma-yuzde-59-ubaglamindan-koparilmis

19- Covid-19: Yanlıș bilgi türleri, kaynakları ve iddiaları [İnternet]. 2020[Erişim tarihi: 10 Haziran 2020]. Erişim adresi: https://teyit.org/covid-19-yanlis-bilgiturleri-kaynaklari-ve-iddialari/

20-Tagliabue F, Galassi G, Mariani P. The "Pandemic" of disinformation in COVID19. SN Compr. Clin. Med. 2020; 1-3.

21- Tüzün H, Demirköse H, Özkan S, Uğraş Dikmen A, İlhan MN. COVID-19 Pandemisi ve Risk İletişimi. Gazi Sağlık Bilimleri Dergisi, 2020; 1-8.

22- Aydın, A. F. (2020). Post-Truth Dönemde Sosyal Medyada Dezenformasyon: Covid-19 (Yeni Koronavirüs) Pandemi Süreci. Asya Studies-Academic Social 
Studies/Akademik Sosyal Araștırmalar, Year:4, Number: 12, Summer, p. 76-90.

23- Mian A, Khan S. Coronavirus: the spread of misinformation. BMC Medicine, 2020;18(89):1-2.

24- Depoux A, Martin S, Karafillakis E, Preet $\mathrm{R}$, Wilder-Smith A, Larson $\mathrm{H}$. The pandemic of social media panic travels faster than the COVID-19 outbreak. JTM. 2020;1-2.

25-Çelik R. Tık Odaklı Habercilikte "Tık Yemi" Taktiği: Koronavirüs (Kovid-19) Örneği. Social Sciences Research Journal. 2020; 9 (2):14-25.

26- Koronavirüs (COVID-19) Salgını Hakkında Bilgi Notu - 2 [İnternet]. 2020 [Erişim tarihi: 11 Haziran 2020]. Erişim adresi:

https://konda.com.tr/tr/duyuru/koron avirus-covid-19-salgini-hakkinda-bilginotu-2/

27- NajmulIslam A.K.M, Laato S, Talukder S, Sutinen E. Misinformation sharing and social media fatigue during COVID-19: An affordance and cognitive load perspective. Technological Forecasting \& Social Change. 2020; 159:1-14.

28-Altınkaya Z. 2020 Koronavirus Pandemisinde Avrupa Birliği Sağllk Politikaları ve Neoliberalism: İtalya Örneği. Yalova Sosyal Bilimler Dergisi. 2020; (20):1-31.

29- 8 soruda ABD sağlık sistemi: Kovid-19 tedavisi 30 bin dolar mi? [İnternet]. 2020[Erişim tarihi: 11 Haziran 2020]. Erişim adresi: https://www.gzt.com/jurnalist/8soruda-abd-saglik-sistemi-kovid-19tedavisi-30-bin-dolar-mi-3532076

30-Viral Yalanlar: Yanlış bilgi ve koronavirüs [İnternet]. 2020 [Erişim tarihi: 1 Haziran 2020]. Erişim adresi: https://www.article19.org/wpcontent/uploads/2020/03/Coronaviru s-final-Turkish-final-final.pdf

31-Van Dyck C, Taylor N. Preserving scholarly content in an era of internet in security. Elsevier, 2017.

32- Laato $S$ ve ark. What drives unverified information sharing and cyberchondria during the COVID-19 pandemic? The Operational Research Society, 2020;118.

33-Gazendam A, Ekhtiari S, Wong E, Madden K, Naji L, Phillips M ve ark. The "Infodemic" of Journal Publication Associated with the Novel Coronavirus Disease. J Bone JointSurg Am.2020; 102(64):1-4.

34- COVID-19 ve DAMGALAMA [İnternet]. 2020 [Erişim tarihi: 1 Haziran 2020]. Erişim adresi: https://www.psikiyatri.org.tr/uploadFi les/243202019327-

DamgalanmaCOVID.pdf

35-Rochwerg B, Parke R, Murthy S, M.Fernando S, Leigh J, Marshall J ve ark. Misinformation During the Coronavirus Disease 2019 Outbreak: How Knowledge Emerges From Noise. Critical Care Explorations. 2020;2:1-6.

36- Vidal-Alaball J, Acosta-RojaR, Hernández N, Luque U, Morrison D, Pérez $\mathrm{S}$ ve ark. Telemedicine in the face of the COVID-19 pandemic. Aten Primaria. 2020;52(6):418-422.

37- Hua J, Shaw R. CoronaVirus (COVID-19) "Infodemic" and Emerging Issues through a Data Lens: The Case of China. Int. J. Environ. Res. Public Health. 2020; 17:1-12. 